\title{
The National Academy of Sciences, India (NASI) \\ 5, Lajpatrai Road, Allahabad - 211002
}

\section{NASI-YOUNG SCIENTIST PLATINUM JUBILEE AWARDS FOR THE YEAR 2013}

NASI invites nominations for the above awards for the year 2013. The nominee should be an Indian citizen / Overseas citizen of India working in India and below the age of 35 years as on April 15, 2013. The award has been instituted by the NASI to recognize promise, creativity and excellence in young scientists. The award shall be made in recognition of notable contributions made by him/her in any branch of S\&T recognized by the NASI on the basis of work carried out in India.

Number and Value of Awards

The number of awards to be made in any year will be limited to five. Each award carries a Citation, Bronze Medal and Rs. 25,000 in cash.

Nominators and Last Date

A candidate may be proposed by a Fellow of the National Academy of Sciences, India. Scientific Society of national standing, university faculty, Post-Graduate department or research institutions may also make nominations of eligible candidates.

A candidate may only be nominated once. However, a nomination will remain valid for consideration for 3 years or the age eligibility which ever expires earlier.

The nomination shall be made in the prescribed format. 20 copies of nomination form along with only one soft copy (in CD), complete in all respects along with 20 copies of reprints of five most important publications and all supporting documents, must reach the Academy latest by April 15, 2013.

Selection of the Awardees

As per Regulations of NASI.

Presentation of the Awards Meeting.

The presentation of Awards will be made by the President, NASI, at the time of Annual General Body

Details and Nomination form also available on NASl's website http://www.nasi.org.in and http://www.nasi.nic.in

\section{NOMINATION FORM}

NASI-YOUNG SCIENTIST PLATINUM JUBILEE AWARDS FOR THE YEAR 2013

(20 Copies of nomination + one CD of the same and 20 copies of reprints of not more than 5 publications which you consider the best; and all supporting documents to be submitted)

1. Name in full (surname, followed by first \& middle name in block letters)

2. Present institutional address and number of telephone, fax and e-mail (any change may be immediately informed)

3. Address for correspondence and number of telephone, fax and e-mail

4. Date of Birth:
Age:
Years
Months
(as on April 15, 2013)

(certificate of the age duly attested by $\overline{\text { Gazetted }}$ Officer/Head of institution must be enclosed.)

5. Academic qualifications (beginning with the Bachelor's Degree in a tabular form)

6. Details of employment and nature of duties

7. Awards and other recognitions received (if any)

8. Field of specialization (Biological (Plant Sciences or Bio-medical Sciences) / Physical / Chemical Sciences)

9. Summary of research work (Not more than three pages)

10. Statement about research contribution of the nominee for which the candidate has been nominated (not exceeding 500 words). Also provide a statement in 50 words which may be used for citation. (the work done in India alone will be the basis for consideration for the award)

11. List of publications and/or patents of the nominee: Information should be provided under three heads: (a) published papers; (b) papers accepted for publication; and (c) five most important publications. Please note that the manuscripts under preparation or abstracts of presentations should not be mentioned. The list should clearly indicate the journal in which the paper was published, year of publication, page number and names of all authors. (Please enclose 20 Set of reprints/photocopies of not more than 5 publications which you consider the best).

12. Name, designation and full address of proposer of the nomination.

Date :

(Signature of the Nominator)

Place : Name \& Address with seal 